\begin{tabular}{|c|c|c|c|}
\hline KULTURA & $\begin{array}{l}\text { POLSKA } \\
\text { KOMITET } \\
\text { INSTYTU }\end{array}$ & $\begin{array}{l}\text { AKADEMIA NAUK } \\
\text { SOCJOLOGII } \\
\text { T STUDIÓW POLITYCZNYCH }\end{array}$ & $\frac{\text { ISSN 0023-5172 }}{\mathrm{I}}$ \\
\hline SPOLECLESTM & 2015, nr 1 & CZYTAJĄC ELIASA & \\
\hline
\end{tabular}

RADOSŁAW KOSSAKOWSKI

Uniwersytet Gdański

\title{
CHULIGAŃSTWO CZY FIGURACJA W PROCESIE CYWILIZOWANIA? RECEPCJA SZKOŁY LEICESTER A ŚWIAT POLSKICH KIBICÓW PIŁKARSKICH*
}

\section{WPROWADZENIE — NORBERT ELIAS I ZNACZENIE SPORTU}

Dokonania szkoły Leicester nie byłyby możliwe bez dziedzictwa intelektualnego Norberta Eliasa. Był on bez wątpienia jednym z najważniejszych myślicieli, którzy na poważnie wzięli pod lupę sport jako zjawisko społeczne, zgodnie z założeniem, że „wiedza o sporcie jest wiedzą o społeczeństwie” (Elias 1986a, s. 19). Widział w sporcie naturalne laboratorium, dzięki któremu można badać kluczowe aspekty egzystencji ludzkiej (Dunning 1992, s. 215). Jego wgląd w rozwój społeczeństw zachodnich (przede wszystkim brytyjskiego) pozwolił dostrzec, że przeobrażanie się aktywności fizycznych nacechowanych przemocą i pozbawionych reguł (zob. Peisert 2013) w specyficzną dziedzinę, w której reguły postępowania coraz bardziej „cywilizują” akty rywalizacji, stanowi znaczącą oznakę procesów cywilizowania się w ogóle. Proces „sportyzacji” (Elias 1986b, s. 151; Malcolm 2012, s. 46) można postawić obok „parlamentaryzacji”, procesu pochodzącego wprawdzie $z$ innych domen, ale o podobnej tendencji rozwojowej. „«Parlamentaryzacja» klas posiadaczy ziemskich Anglii miała swój odpowiednik w "usportowieniu» tamtych czasów" (Elias 1986a, s. 34).

Dostrzeżenie, że w sporcie znajdują odzwierciedlenie szersze procesy społeczne, stało się istotnym argumentem dla Erica Dunninga, wykorzystywanym

Adres do korespondencji: radkoss@wp.pl

* Artykuł powstał dzięki projektowi badawczemu „Znaczenie futbolu. Społeczne wymiary kultury kibicowania" finansowanemu ze środków Narodowego Centrum Nauki (nr grantu 2013/09/D/HS/6/00238). 
w jego pracach nad kibicowaniem (czy sportem w ogóle, zob. Dunning 1999). Rozpatrywał on zjawisko football hooliganism, sięgając aż do XIX wieku, kiedy to profesjonalna piłka nożna stawiała pierwsze kroki w Wielkiej Brytanii. Wzrosty i spadki liczby aktów wandalizmu na brytyjskich stadionach w poszczególnych dekadach pozwoliły oszacować, jak przebiegał proces cywilizowania społeczeństwa brytyjskiego w ogóle.

Fakt, że w toku dziejów zarówno w sporcie, jak i w innych dziedzinach życia dokonywał się proces wzrostu samokontroli, łagodzenia obyczajów i wykluczania zachowań agresywnych, jest istotny również w kontekście nowoczesnego (czy ponowoczesnego) stylu życia. Konieczność powściągania emocji w środowisku pracy czy w innych domenach życia wymusza poszukiwanie enklaw, w których można przeżyć podniecenie i podekscytowanie. Nowoczesny sport doskonale wpisuje się $\mathrm{w}$ taką potrzebę. Jest rodzajem „mimetycznej aktywności”, w której formy uspołecznienia i towarzyskości są blisko powiązane, ale na swój sposób odmienne od tego, czego ludzie doświadczają w swym zwyczajnym życiu (Elias, Dunning 1986, s. 124).

„Sport uprawiany dobrowolnie nakierowany jest przede wszystkim na czerpanie satysfakcji z zaangażowania się $\mathrm{w}$ fizyczne działanie, ze społecznych kontaktów tworzonych przez sporty, oraz z pobudzenia emocji, które przypominają w sposób zabawny i przyjemny afekty generowane w poważnych, krytycznych sytuacjach" (Dunning 1999, s. 3).

Elias (1986a, s. 59) jest dość lapidarny w stwierdzeniu, że w społeczeństwach „wysterylizowanych” oprócz seksu ludzie potrzebują ekscytacji „bitewnych", które społeczeństwo powinno zapewnić.

W tej konstatacji ukryte są jednak dodatkowe znaczenia. Odnoszą się one do problematyki tożsamości i identyfikacji. Rywalizacja (np. z innymi sportowcami lub z własnymi słabościami) stanowiąca cechę definiującą sport (Giulianotti 2005 , s. xii) może być istotną warstwą sensotwórczą, gdy inne sfery życia są emocjonalnie, politycznie czy kulturowo „wygładzone”. Walka z innymi grupami fanów to nie tylko fizyczna bójka: „kontekstowa reewaluacja opozycyjnej formacji służy unifikacji wewnętrznej jednostek w chuligańskiej formacji" (Giulianotti, Armstrong 2002, s. 217). Kibicowanie swojej drużynie (w odróżnieniu od „ich” drużyny), oparte na rywalizacji z innymi, może dostarczać źródeł autoidentyfikacji, co wyróżnia świat piłkarski pod różnymi szerokościami geograficznymi (zob. Armstrong, Giulianotti 2001). Pojawiają się tutaj jednak co najmniej dwie ewentualności. Po pierwsze, wraz z podporządkowaniem znaczących połaci domeny sportowej regułom rynkowym tożsamość różnicy traci na ostrości. Dla biznesu najważniejsze są portfele kibiców, a nie ich lokalne animozje. Rynek zatem wnosi wkład w proces cywilizowania kibiców i sportu na drodze komodyfikacji, co w pewnym sensie zmniejsza krok po kroku możliwości ucieczki od sterylności dnia codziennego (w którym kolejne sfery podlegają „supermarketyzacji”). Po drugie, część kibiców 
sprzeciwia się jednak takiej formie „urynkowionego” performansu (zob. Kossakowski 2014a). Ich kontestacyjne zachowania mogą być oceniane jako „niecywilizowane”. Rynkowy suweren, który podporządkowuje sobie za pomocą międzynarodowych organizacji sportowych (UEFA, FIFA czy MKOl) kibiców, sportowców, ale i władze poszczególnych państw (np. za pomocą wymuszanych zwolnień podatkowych dla sponsorów globalnych sport mega events, zob. Tetłak 2012), ustanawia w ten sposób nowych „outsiderów”, których plemienne zachowania nijak nie przystają do konsumentów zachęcanych do indywidualnych aktów „ekscytacji”.

Zdychotomizowane pola konfliktu (konstytuowane przez kibiców i organizacje piłkarskie) stanowią przenikające się wzajemnie „figuracje”. Stanowią one kompleks współzależnych polaryzacji funkcjonujących w stanie niestabilnego equilibrium (Elias 1986b, s. 157). Obie strony próbują „postawić na swoim”, choć dysponują zróżnicowanym arsenałem środków. Gra polega na „przeciąganiu” liny: „koncepcja chwiejnej równowagi władzy czy stosunków władzy jest centralna w procesualnej socjologii" (Dunning, Malcolm, Waddington 2004, s. 195). W czasach gdy Eric Dunning eksplorował środowisko fanów futbolowych, fundamentalna gra o pozycje toczyła się między grupami chuliganów a władzami (policją, rządem) i mediami (te włączyły się do „gry” w drugiej połowie lat sześćdziesiątych XX wieku). Obecnie wszystkie te podmioty funkcjonują współzależnie, a oprócz tego istnieje dominujący sektor biznesu.

\section{KORZENIE STADIONOWEGO CHULIGAŃSTWA}

Interpretacja świata kibiców stworzona przez przedstawicieli szkoły z Leicester nie jest oczywiście jedyna. Jeżeli chodzi o Wielką Brytanię, to wymienia się co najmniej pięć akademickich podejść do zjawiska chuligaństwa stadionowego. Są to podejścia: antropologiczne (zob. Armstrong 1998), marksistowskie (Taylor 1971), etologiczne (Marsh i in. 1978) czy psychologiczne (Kerr 1999). Piątym jest omawiane tutaj podejście figuracyjne. Richard Giulianotti (1999, s. 148) wspomina jeszcze o typie wyjaśnienia postmodernistycznego, dotyczącego zjawiska post-fandom. Tożsamość tego ostatniego jest kreowana na nowo w dużej mierze przez media i rynek. Dodatkowa, uwspółcześniona perspektywa jest niezbędna, ponieważ pięć pierwszych interpretacji nie opiera się próbie czasu i trudno uznawać je za miarodajne dla współczesnych zjawisk. Piłka nożna oraz kultura kibicowania nieustannie ulegają fluktuacjom.

Ramón Spaaij (2006, s. 22) wspomina o trudnościach z konceptualizowaniem zjawiska stadionowego chuligaństwa. Czasami przemoc pojawia się żywiołowo, jest wynikiem „przedłużenia” symbolicznej rywalizacji fanów w spontanicznej chwili. Na meczu polskiej ekstraklasy Lechia Gdańsk-Legia Warszawa (rozgrywanym w Gdańsku) piłkarz ze stolicy po zdobyciu bramki podbiegł pod trybunę kibiców gospodarzy i celebrował tę chwilę między innymi 
przez całowanie herbu swojego klubu na koszulce. Cześć kibiców zareagowała wściekłością, rzucając się na płot odgradzający od murawy i celując w niego różnymi przedmiotami. Pytanie jednak, ile $z$ tych osób to „prawdziwi” chuligani regularnie angażujący się $\mathrm{w}$ akty przemocy? Czy osoby, które dopuszczają się przemocy werbalnej, to również stadionowi chuligani? Czy chuliganami stadionowymi są tylko ci, którzy dążą do konfrontacji z grupami fanów innych drużyn (na tym wyróżniku opiera swoją definicję Spaaij), czy również ci, którzy rzucają epitetami i przedmiotami w stronę policji? Do tego należy doliczyć różnice w poszczególnych krajach, by uświadomić sobie, że uniwersalna konceptualizacja zjawiska wymaga analizy wielu niuansów. Inną kwestią, którą również należy tutaj podjąć, jest fakt redukowania (między innymi przez media) kultury kibicowania do jej aspektu „chuligańskiego", który był chyba najbardziej wyeksponowany w analizach socjologów, choć stanowi zaledwie małą część football fandom. O tym należy bezwzględnie pamiętać.

Środowisko kibiców przeżyło zmiany pokoleniowe, ale także klasowe. Tym bardziej zasadne staje się historyczno-socjologiczne spojrzenie na fanów futbolu. To metodologiczna wskazówka bliska uczniom Norberta Eliasa. Podejście historyczne umożliwia obserwację rozwoju zjawisk w ujęciu diachronicznym, socjologiczne zaś - wyjaśnienie znaczenia różnych czynników społecznych. Przemoc na stadionach datuje się od chwil konstytuowania się piłki nożnej w sposób formalny, w Anglii jest to druga połowa XIX wieku (Dunning, Murphy, Williams 1988). Badacze wykorzystali doniesienia z prasy (od $1880 \mathrm{roku}$ ) oraz statystyki angielskiego związku piłkarskiego (Football Association) w Anglii (za lata 1895-1959). Wnioski z analizy treści przekonują, że przed pierwszą wojną światową poziom incydentów w tłumie kibiców był wysoki i znacząco zmalał w okresie międzywojennym. Tendencja ta utrzymała się aż do połowy lat pięćdziesiątych XX wieku. Liczba aktów przemocy i wandalizmu zaczęła następnie wzrastać, najpierw bardzo nieznacznie, a od połowy lat sześćdziesiątych proces ów nabrał tempa.

Fakt zmniejszania się liczby aktów agresji między 1918 a 1939 (i dalej, aż do lat pięćdziesiątych) Dunning (2003, s. 76) tłumaczy jako funkcję „faktu, że wyższe standardy zachowań zaczęły być wymagane od tłumu na meczach", czyli postępu cywilizowania klasy robotniczej w Anglii. W owym czasie rósł dobrobyt klasy robotniczej, na trybunach pojawiało się więcej kobiet, co również nie pozostawało bez wpływu na zachowanie publiczności. Pozostaje jednak niewyjaśniona kwestia „powrotu” do chuligaństwa w latach sześćdziesiątych. Jednym z powodów był fakt, że nie wszystkie segmenty klasy robotniczej doświadczyły procesu ucywilizowania w równym stopniu. Okazało się, że na poziomie lower working class funkcjonowały tzw. 'rough' sections (Dunning, Murphy, Williams 1986, s. 234). Z tych segmentów rekrutowała się największa liczba stadionowych chuliganów, a ich znaczenie rosło pod koniec lat sześćdziesiątych (i zachowało się właściwie do końca lat osiemdziesiątych). Dla klasy „nieokrzesanych” 
przemoc była często jedynym źródłem prestiżu ${ }^{1}$, w odróżnieniu od tych części struktury brytyjskiego społeczeństwa (nazywanych respectable sections), które zostały inkorporowane $\mathrm{w}$ proces cywilizacyjny, a których członkowie wstydzili się aktów przemocy.

Autorzy wymieniają wiele przyczyn takiego stanu rzeczy (Dunning, Murphy, Williams 1986, s. 241). Z najważniejszych należy wymienić przemiany strukturalne $\mathrm{w}$ wymienionych segmentach (rough i respectable), nowe możliwości spędzania czasu wolnego (stąd spadek frekwencji na meczach - część przedstawicieli klasy robotniczej zaczęła korzystać z innych dostępnych możliwości), zwrot w kształtowaniu obrazu kibiców w mediach (połowa lat sześćdziesiątych), kryzys rynku pracy dla młodych ludzi czy rosnąca popularność podróżowania na mecze wyjazdowe (przez co rosło ryzyko konfrontacji z innymi grupami). Miejsca na stadionach „opuszczone” przez klasę respectable zaczęły były zapełniane przez nowe subkultury (Mod's, Rocker's, Teddy Boys czy Skinheads), przyciągane przez coraz bardziej powszechne w mediach sprawozdania $z$ walk i aktów wandalizmu na meczach. Wątek znaczenia mediów zostanie jeszcze podjęty, wydaje się jednak, że najważniejszym punktem do dyskusji o źródłach chuligaństwa stadionowego jest struktura środowiska „nieokrzesanej” klasy robotniczej, analizowana przez Dunninga w szerszym kontekście inkorporacji w proces cywilizacyjny.

Dla przedstawicieli rough class sport jest przede wszystkim źródłem możliwości konfrontacji i zademonstrowania siły fizycznej, w odróżnieniu od innych klas, które szukają w nim „bezpiecznej” ekscytacji. Przyczyna — jak zauważa również Alan Bairner (2006, s. 587) - leży w procesie socjalizacji poza „kontekstem cywilizowania". Metaforycznie mówiąc, strumień cywilizowania zachowań nie wpłynął do ulic i osiedli zamieszkiwanych przez „nieokrzesaną” klasę robotniczą. To nie oznacza, że mieliśmy do czynienia z odgórnie zamkniętymi gettami, raczej ze skupiskami ludzi, którzy żyli w środowisku „wąskiej homogeniczności doświadczenia” (Giulianotti 2005, s. 145). Socjologowie $z$ Leicester używali w tym kontekście sformułowania ordered segmentation (zapożyczonego od Gerarda Suttlesa), opisującego społeczności, w których zunifikowane podejścia do seksualności, pochodzenia etnicznego oraz terytorialności uzupełniają się wzajemnie. Są to enklawy społecznie homogeniczne, któ-

${ }^{1}$ Richard Giulianotti i Gary Armstrong (2002, s. 217) piszą również o „honorze” i „rynku”, na którym grupy chuligańskie mogą walczyć o swój status i rozgłos. Faktycznie, niektóre z „ekip” uzyskały renomę w świecie chuligańskim, co z pewnością miało wpływ na decyzję opublikowania wspomnień przez ich członków. W Polsce wydano między innymi wspomnienia chuliganów West Ham United i Chelsea Londyn (zob. Pennant 2009; King, Knight 2008). Również w Polsce pojawiały się rankingi „ligi chuliganów”, zwłaszcza w latach dziewięćdziesiątych XX wieku, kiedy okazji do konfrontacji było znacznie więcej. Obecnie informacje o pojedynczych „ustawkach” („banda na bandę") w miejscach niezwiązanych $z$ futbolem pojawiają się między innymi w miesięczniku „To My Kibice”. Ciekawa jest metaforyka opisująca takie bójki: „rugby bez piłki”, „spotkali się”, „spotkanie na ubitej ziemi”. 
rych wzajemna współpraca następuje według wzoru odzwierciedlonego przez „syndrom Beduina” (Dunning, Murphy, Williams 1986, s. 230). Łączą one na przykład siły w przypadku „najazdu” wspólnego „wroga” (a takim byli przyjezdni kibice).

Norbert Elias (2008) pisał o rosnącej współzależności jednostek, ale opisywani chuligani grali bierną rolę $\mathrm{w}$ procesie wzrostu współzależności społeczeństwa (Dunning, Murphy, Williams 1988, s. 228-229). Przedstawiciele rough class doświadczają uprzedzeń ze strony grup established, głównie za sprawą credo law and order (Giulianotti 2005, s. 146). W ostatnich kilku dekadach w Wielkiej Brytanii wprowadzono kilkanaście aktów prawnych, które w sposób restrykcyjny odnoszą się do zaburzania porządku na meczach piłkarskich i wokół nich (niektóre $z$ rozporządzeń rodzą wątpliwości w kontekście europejskich konwencji praw człowieka; zob. Giulianotti 2011). Jak przekonuje Anastassia Tsoukala (2009), miało to związek z kreowaniem „inności”. Jej ucieleśnieniem byli chuligani wywodzący się z tych segmentów społeczeństwa, w których tendencje do samokontroli nie stały się czymś powszechnym. Wykreowanie „obcości”, „choroby”, „zezwierzęcenia” (metaforyka chuliganów jako animals zaczęła dominować w mediach brytyjskich od drugiej połowy lat sześćdziesiątych) usprawiedliwiało wprowadzenie środków zaradczych. Figuracyjni socjologowie sugerowali rozwiązywanie problemów raczej przez redukowanie nierówności oraz podnoszenie znaczenia kobiet, co osłabiłoby „agresywny maskulinizm" (zob. Dunning, Murphy, Williams 1988).

Zamknięte enklawy uniemożliwiały przenikanie różnorodnych wzorców zachowań. Brak inkorporacji norm oficjalnych w drodze dyfuzji aksjologicznej czy kulturowej dotyczył mechanizmów edukacyjnych. Szkoła kojarzyła się z restrykcyjną kontrolą i mentalną dominacją w odróżnieniu od ulicznej „wolności”. Dunning (1999, s. 149) przekonuje, że niski poziom scholaryzacji tej grupy jest czynnikiem sprzyjającym przemocy i agresji. Dominują tu silne więzi oparte na szowinizmie, segregacja ze względu na wiek i płeć (instrumentalne traktowanie kobiet jako obiektów seksualnych przy jednoczesnym przywiązaniu do matek kierujących gospodarstwem domowym), nabywanie wzorców zachowań na zasadzie ulicznego "prawa pięści”.

Niski poziom edukacji jest rekompensowany przez wzór twardej, silnej męskości, której tożsamości zagraża nie tylko „feminizacja”, ale jakiekolwiek „płynne” kulturowe tendencje (Dunning 1999, s. 147-150). Szowinizm i przemoc wobec wszelkich „innych” (etnicznych, rasowych czy klasowych) może się symbolicznie wyrażać w walce $z$ kibicami innych drużyn. Konfrontacja podczas meczu legitymizuje siłę i prestiż grupy, co jest wzmacniane przez relacje w mediach. Najbardziej krytyczne i odwołujące się do metaforyki upodlenia, degrengolady opisy stanowiły pożywkę dla chuliganów, którzy nie traktowali tych zachowań jako „niecywilizowanych” (zgodnie ze twierdzeniem Eliasa o „podniesionym poziomie zakłopotania” oraz „progu odrazy”; zob. Best 2010, s. 575). 
Niektórzy komentatorzy dokonań Dunninga uważają, że w analizie świata chuliganów zrzekał się on koncepcji „figuracji” na rzecz „inkorporacji”, w której centrum lokowało się pojęcie kulturowo zdeprawowanej rough underclass (Best 2010, s. 575). Rzeczywiście w jednej z prac „inkorporacja” pojawia się w rozumieniu „konstelacji rozwojowych służących włączeniu mas klasy robotniczej w mainstream" (Dunning, Murphy, Williams 1988, s. 227). Ale to nie oznacza, że założenia przyświecające pojęciu figuracji Dunning uznał za nieprzydatne. Wspomina on bowiem, że proces figuracyjny można potraktować „jako historyczne i socjologiczne podejście do chuligaństwa, które jest rozwojowe. Pomaga eksplorować znaczenia zachowania chuligańskiego przez analizę stanowisk słownych, lokuje chuligaństwo piłkarskie w szerszej strukturze społecznej, zwłaszcza w systemie klasowym i bada dynamikę relacji między chuliganami a innymi społecznymi grupami" (Dunning 2000, s. 155). Dunning nakreśla homogeniczny charakter rough sections, ale $z$ drugiej strony nie ucieka od wyjaśnień wpływu takich czynników jak media, edukacja (jej niewystarczający poziom), rynek pracy (bezrobocie, ograniczone umiejętności zawodowe). Sieci współzależności z resztą społeczeństwa były „osłabione”, ale nie można kategorycznie stwierdzić, że ich nie było.

Agresywne zachowanie mężczyzn z lower working class odnosi się nie do sfery instynktów, ale do „wyuczonych wzorców zachowań, które są nieustannie generowane w specyficznych społecznych figuracjach. Piłka nożna jest kontekstem, w którym zachowanie jest wyrażane i wzmacniane, ale nie pierwotnie generowane" (Dunning 1999, s. 148). Te swoiste społeczne figuracje charakteryzowały się specyficzną współzależnością, konstytuującą się na ulicach sąsiadujących ze sobą ordered segmentations. Większość relacji była ograniczona do fizycznego wyznaczania trajektorii zarówno indywidualnych, jak i grupowych. Następnie inkorporowano te „przemocowe” wzorce zachowania w atmosferę meczów piłkarskich. Z pewnością silniejsze więzi charakteryzowały grupy z najbliższych „klasowych” okolic, jednak nie były to zamknięte getta bez przepływów (choćby w ograniczonym stopniu) kapitałów kulturowych i społecznych $z$ innych sfer.

\section{KRYTYKA STANOWISKA FIGURACYJNEGO}

Ocena rozstrzygnięć szkoły Leicester zawiera dużą dozę krytyki. Richard Giulianotti wspomina (1989), że żadna klasa społeczna nie żyje w zamknięciu, przenikając się z innymi, należy zatem ostrożnie podchodzić do wniosków „zamykających" procesy normotwórcze w enklawach społecznych. Ta linia argumentacyjna jest warta podjęcia przede wszystkim współcześnie, kiedy to zdecydowanie nie da się obronić tezy o „segmentacji” klasowej wśród fanów piłkarskich. Publiczność na stadionach brytyjskich charakteryzuje się obecne innymi społecznymi właściwościami, a najniższe warstwy klas społecznych zostały po prostu relegowane za pomocą instrumentów ekonomicznych (zjawisko 
priced out; zob. Giulianotti 2011) lub restrykcji prawnych. Niestety, analizy zespołu Dunninga nie były aktualizowane (najważniejsze wnioski postbadawcze powstały na przełomie lat osiemdziesiątych i dziewięćdziesiątych XX wieku). Skądinąd byłoby niezwykle ciekawe kontynuowanie procesualnego podejścia do tematu, który szkoła Leicester badała od jego źródeł w XIX wieku. Czy stwierdzono by inkorporowanie „ordynaryjnych” segmentów w strumień cywilizowania? Jak wyglądają obecnie te miejsca w Leicester, w których mieszkała rough class? Jaki wpływ miałyby grupy emigrantów z różnych kultur osadzających się Wielkiej Brytanii?

Wróćmy jednak do „przenikania” wzorców — do agresywnych chuliganów z pewnością musiały docierać medialne doniesienia z "zewnętrznego" świata. Dunning analizuje rolę mediów w „promowaniu” chuligańskich wybryków. Przypomina, że w pierwszej połowie XX wieku prasa brytyjska nie odzwierciedlała wiarygodnie liczby incydentów na stadionach, istotnie je zaniżając (Dunning 2003, s. 79). Służono tym samym mitowi o dobrym „ułożeniu” tłumów. Sielanka w obrazach medialnych trwała do połowy lat sześćdziesiątych, a ich zmiana ma związek z Mistrzostwami Świata, których Anglia była gospodarzem w 1966 roku. Na łamach gazet zaczęto dostrzegać nie tylko poważne incydenty, ale również te zaburzenia porządku, które nie prowadziły do przemocy. Dziennikarze próbowali uchronić kraj przed złą reputacją, którą goście $z$ różnych kontynentów mogliby upowszechniać po powrocie do swoich krajów. Tymczasem efekt był paradoksalny - histeryczne, odwołujące się do metaforyki bitewnej i wojennej przekazy zadziałały inspirująco na tych, dla których fizyczna konfrontacja stanowiła codzienność.

Richard Giulianotti (1999) punktuje także inne słabe strony koncepcji „figuracjonistów". Twierdzi, że teoria Norberta Eliasa jest niesprawdzalna (Dunning wspomina, że nie jest to „metateoria” zdolna wyjaśniać wszystko). Kolejna kwestia: podejście Leicester zawiera historyczne nieścisłości oraz nie wykazuje się wystarczającym zrozumieniem dla innych narodowych kontekstów (jest „anglocentryczne”). Oparcie się na danych zastanych przy jednoczesnym braku pogłębionych studiów etnograficznych świadczy o metodologicznej słabości podejścia Dunninga i jego zespołu (oprócz danych piłkarskiej centrali i gazet wzięto pod uwagę program telewizyjny o chuliganach oraz ich wypowiedzi $z$ innych badań). Giulianotti (2005, s. 148) wskazuje też, że dane pochodzące $z$ Leicester powinny być uzupełnione o analizę porównawczą kibiców innych drużyn wymykających się jednoznacznemu klasowemu sklasyfikowaniu. „Pierwsze spojrzenie na ich odzież, dziewczyny, rodziców, domy, samochody, pracę, szersze środowisko i zainteresowania w zrozumiały sposób zaświadcza o zwykłym, nawet banalnym stylu życia tych, którzy są dobrze zintegrowani z głównym nurtem brytyjskiego społeczeństwa" (Giulianotti 1999, s. 49). Alan Bairner (2006, s. 589) przytacza innych badaczy wskazujących przykłady bardziej wykształconych członków ekip chuligańskich (nawet radców prawnych i lekarzy). 
Dane nie pochodzące ze statystycznie reprezentatywnych badań trudno uznać za przekonujące, jednak kompleksowość i zmienność (jak przystało na procesualnego socjologa) klasowych uwarunkowań dostrzegał także Dunning. Na przykład rynek ekonomiczny stawia coraz wyższe progi nawet tym członkom working class, którzy są „zinkorporowani”. Geoff Pearson (2012, s. 77) pokazuje, że „fan z klasy robotniczej” staje się niekiedy szacownym wzorem do zaadaptowania, zwłaszcza podczas podróży na mecze do innego miasta bądź kraju. „Stary styl”, zawierający rubaszny maskulinizm, intensywną konsumpcję alkoholu i klimat „karnawału”, został przefiltrowany przez postmodernistyczne warunki futbolu drugiej dekady XXI wieku. Kibice odwołują się do korzeni working class, ale większość z nich nie kieruje się zsocjalizowanymi wzorcami rough sections (których skomercjalizowana rozrywka po prostu nie dopuszcza).

Krytyka Giualinottiego i Armstronga (2002, s. 219-221) dotycząca użycia schematu interpretacyjnego ordered segmentation wydaje się zasadna. Wskazują oni, że oprócz zróżnicowania demograficznego fani tych samych klubów wywodzą się nie tylko $z$ różnych miejsc $\mathrm{w}$ kraju, ale również $\mathrm{z}$ oddzielnych osiedli miejskich. Nie przeszkadza to im w zwieraniu szeregów $w$ walce $z$ kibicami innych ekip. Stają ramię w ramię bez względu na zaawansowanie w przyswajaniu oficjalnych wzorów społeczeństwa (zarówno w Sheffield, jak i Edynburgu - miejscach, w których ci badacze prowadzili eksplorację etnograficzną ekipy chuliganów wywodziły się z różnych osiedli oraz z różnych warstw klasowych). Pojawia się także zarzut o brak wyjaśnienia przyczynowej dynamiki ordered segmentation (Czy jest nieuchronna? Czy wynika z psycho-społecznych atrybutów gangów? Czy jest raczej rodzajem mitu utrzymywanym przez przywódców grup w celu utrzymywania kontroli?). Najważniejsza kwestia dotyczy „znieczulenia” na czasowe i kulturowe wariacje w manifestowaniu się zachowań chuligańskich/kibicowskich.

Ważnym ogniwem krytyki osiągnięć szkoły Leicester był argument „klasowy”. Z jednej strony wskazywano na większe zróżnicowanie demograficzne grup chuligańskich, wątpliwości rodzi również wyjątkowość i jednolitość „nieokrzesanej” części klasy robotniczej. „Przez użycie terminu rough working class sugeruje się, że problemy biednych ludzi pojawiają się jako specyficzne dla nich, tymczasem w rzeczywistości rough working class dzieli wiele problemów z klasą robotniczą $\mathrm{w}$ ogólności. Zwłaszcza relatywny brak szans życiowych, stosunkowy brak władzy i zasobów, wyniki w edukacji poniżej średniej i ograniczony dostęp do lepiej płatnych zawodów na rynku pracy" (Best 2010, s. 582). Powyższa konstatacja nie tylko obnaża słabość wyjaśnienia Dunninga, ale także kieruje uwagę w stronę współzależności różnych aktorów społecznych.

\section{ODPOWIEDŹ NA KRYTYKĘ}

Dunning nie pozostawił licznych głosów krytycznych bez odpowiedzi. Skupię się tu tylko na dwóch punktach: „klasowości” chuliganów oraz możliwości 
przeniesienia wniosków poza brytyjski kontekst. Dunning wskazuje, że określenie rough nie jest definiowane w terminach ubóstwa i nieokrzesanych manier, ale w terminach wartości odnoszących się do przemocy i inicjacji do walki. „Nigdy jednakże nie mieliśmy zamiaru dawać do zrozumienia, że takie wspólnoty są zawsze i wszędzie strukturalnie i kulturowo identyczne lub że chuligani piłkarscy nigdy nie wywodzili się ze społeczności innego typu. Rzeczywiście, dostępne dowody sugerują, że od lat sześćdziesiątych mniejszość z nich zawsze wyłaniała się z wyższych poziomów na społecznej skali" (Dunning 1992, s. 146). To stwierdzenie rozwiewa wiele wątpliwości, nie tylko podnoszonych przez adwersarzy, ale i związanych z „eliasowskim dziedzictwem”, oznacza bowiem przyznanie, że nawet tak radykalne formacje jak grupy chuliganów, chociaż dopuszczają się „niecywilizowanych” aktywności, stanowią zróżnicowane figuracje ${ }^{2}$.

Zróżnicowanie musi być wzięte pod uwagę, jeżeli chcemy się pokusić o przekroczenie granic narodowych w celu znalezienia uniwersalnych cech chuligaństwa piłkarskiego. Na zarzut ,anglocentryzmu” Dunning (1992, s. 147) odpowiada lapidarnie: „Retrospektywnie myślę, że nasza najważniejsza książka powinna być raczej zatytułowana The Roots of English Football Hooliganism, ponieważ taki tytuł mógłby pomóc w uniknięciu wrażenia, że próbowaliśmy rozwijać jakiś rodzaj uniwersalnej teorii. Nie próbowaliśmy". W tym samym miejscu donosi jednak, że pewną uniwersalność stanowi przemoc - cecha nieodłącznie związana z piłką nożną (co podkreślał także Elias). Z kolei w innym miejscu posuwa się jeszcze dalej konstatując, że samo zjawisko chuliganizmu piłkarskiego powinno być rozpatrywane jako uniwersalny fenomen, choć przy założeniu, że jest jednak „nieprawdopodobne, by fenomen chuligaństwa piłkarskiego mógł wszędzie wyrastać z tych samych korzeni" (Dunning 2000, s. 158). Ramón Spaaij (2006, s. 6) uważa natomiast, że „musimy analizować, jak ogólne społeczne podziały są interpretowane i ucieleśniane w specyficznych fanowskich i chuligańskich tożsamościach i jak one interagują z bardziej specyficznymi (lokalnymi) społecznymi, historycznymi i kulturowymi czynnikami. Takie analizy umożliwią nam zidentyfikowanie głównych wzorów międzynarodowych

\footnotetext{
2 Eric Dunning (2003, s. 89) przytacza dane, które wskazują na klasowe zróżnicowane fanów: „Z 519 pracujących chuliganów piłkarskich aktywnych w latach sześćdziesiątych, siedemdziesiątych lub osiemdziesiątych, o których mamy informacje; $0,38 \%$ pochodzi z klasy społecznej 1, 2,5\% z klasy 2; 5,58\% z klasy 3 (prace niemanualne); 18,88\% z klasy 3 (zawody manualne); 25,43 z klasy 4 i 47,2\% ze społecznej klasy 5". Numery klasy są związane w socjo-ekonomicznym wskaźnikiem o nazwie Registrar General's Social Class wprowadzonym w Wielkiej Brytanii w 1913 roku i w 1990 roku przemianowanym na Social Class based on Occupation. Numery klas oznaczają: 1 professional occupations (wolne zawody), 2 - managerial and technical occupations (zawody menadżerskie i techniczne), 3N - skilled non-manual occupations (wykwalifikowane zawody nie wykonywane przy pomocy sił manualnych), $3 \mathrm{M}$ - skilled manual occupations (wykwalifikowane zawody wykonywane manualnie), 4 - partly-skilled occupations (częściowo wykwalifikowane zawody), 5 - unskilled occupations (zawody niewykwalifikowane).
} 
i międzylokalnych różnic i podobieństw w manifestowaniu się chuliganizmu piłkarskiego".

Eric Dunning (1999, s. 158) idzie w sukurs takim metodologicznym postulatom: „jest rozsądnym postawić hipotezę, że problem będzie rozwijany oraz nakreślany ceteris paribus przez to, co można nazwać głównymi «liniami podziału» [fault lines] w poszczególnych krajach". Jest to krok uzupełniający i rozszerzający „angielski” charakter dotychczasowych rozważań szkoły z Leicester. Pokazanie, że w poszczególnych miejscach (nie chodzi tylko o kraje, ale o regiony czy miasta) konfrontacje kibiców zależą od innych wartości, tradycji i postaw, ustawia dokonania procesualnych myślicieli w bardziej realistycznym świetle. Przykłady fault lines to na przykład nierówności regionalne i klasowe w Anglii; religijny sektarianizm w Szkocji (katolicki klub Celtic Glasgow i protestancki Glasgow Rangers); subnacjonalizm (językowy i kulturowy) w Katalonii czy w kraju Basków; rozłam na północ i południe we Włoszech; wschód i zachód oraz prawice i lewicę w Niemczech. Wydzielanie osi dystynkcji czy wręcz binarnych opozycji prowadzi aż do najniższych szczebli lokalnych, na przykład podziałów na osiedla kibicujące ŁKS i Widzew (casus Łodzi), podziałów klasowych (suburbia przemysłowe jako enklawy AC Milan versus bogate centrum miasta kibicujące Interowi Mediolan) czy dawnych jednostek reżimu (kluby resortowe w Moskwie: Dynamo podlegające Ministerstwu Spraw Wewnętrznych, CSKA — kombinat wojskowy, Lokomotiw — przemysł kolejowy).

Powyższe przykłady odnoszą się do figuracyjnego stanowiska Norberta Eliasa, który odnotował, że „w centrum zmiennych figuracji lub, inaczej mówiąc, procesu figuracyjnego tkwi oscylująca równowaga napięć, tkwią wahania bilansu sił, który raz wypada na korzyść jednej strony, a raz na korzyść drugiej. Tego rodzaju oscylujące bilanse sił należą do właściwości strukturalnych każdego strumienia figuracyjnego" (Elias 2010, s. 171). Dunning stwierdza, że wszystkie „linie podziału” umożliwiają kreowanie strukturalnych podziałów (podobnych ordered segmentation), „w których mogą się rozwijać intensywne więzi grupowe (we-group) przy korespondencyjnym intensywnym antagonizmie w kierunku obcych (they-group) lub outsiderów" (Dunning 1999, s. 158). Bardzo silne więzi grupowe (we-group właśnie) stanowią cechę dystynktywną kibicowskich ekip w wielu miastach czy krajach (zob. Bairner 2006; Spaaij 2006).

\section{POLSCY OUTSIDERZY I LINIE PODZIAEU}

Norbert Elias (1986a, s. 57) zauważył, iż „przemoc futbolowa [...] powinna być także postrzegana jako syndrom outsiderów, jako forma zachowania i uczuć charakterystycznych dla młodych outsiderów, skłonnych do zbierania się i formowania ogromnego tłumu”. Pytanie: Czy polscy kibice są takimi „outsiderami”, czy doświadczają „uprzedzeń” ze strony grup uprzywilejowanych? Odpowiedź na to pytanie można oprzeć na przedstawieniu punktu widzenia osób zainteresowanych, a następnie rozważeniu, czy nosi on znamiona tożsa- 
mości grup outsiderów. Z jednej strony w polskim dyskursie publicznym mamy do czynienia z głosami silnie piętnującymi zachowania kibiców ${ }^{3}$. Przykładem są oficjalne stanowiska, na przykład premiera polskiego rządu czy ministra spraw wewnętrznych, oraz krytyczne artykuły w niektórych gazetach (stanowią one dowód na wytwarzanie symbolicznego wymiaru habitusu outsiderów; zob. Bucholc 2012). Z drugiej strony dostępne są obiektywne statystyki w archiwach policji, które dotyczą kar za wykroczenia związane z nowelizowaną w 2009 roku ustawą o bezpieczeństwie imprez masowych (dalej „ustawa o b.i.m”).

Ustawa była odpowiedzią na pilną konieczność zapobiegania chuligańskim incydentom na polskich stadionach piłkarskich. Ich liczba rosła w latach dziewięćdziesiątych ubiegłego stulecia, co obrazują statystyki policyjne. W 1991 roku było ich 210, a w 1997 już 1075 (Kamiński 2012, s. 20). Polskie stadiony $\mathrm{w}$ tamtym okresie były obrazem zaniedbań po poprzednim systemie. Do 1989 roku w Polsce nie doszło do tragedii, jak w przypadku Heysel w Brukseli (rok 1985 - śmierć 39 osób w skutek ataku kibiców FC Liverpool na fanów Juventusu Turyn) czy Hillsborough w Anglii (96 ofiar śmiertelnych na skutek błędów w zarządzaniu tłumem), co można zapewne „zawdzięczać” bardzo represyjnym służbom porządkowym PRL-u, czyli milicji i ZOMO, które skutecznie pacyfikowały wszelkie znamiona zarówno chuligaństwa, jak i postaw antysystemowych u kibiców ${ }^{4}$. Po transformacji ustrojowej niewiele zmieniono w zakresie infrastruktury i prawa. Służby policyjne nie miały narzędzi prawnych, stadiony pozbawione były monitoringu, nie było także elektronicznego systemu identyfikacji kibiców. Jednocześnie ruch kibicowski prężnie się rozwijał, rosło również chuligaństwo. Apogeum wydarzeń z tamtych dni był incydent z 19 kwietnia 1997 r. podczas meczu Polonia Warszawa-Legia Warszawa, gdy kibice Legii podpalili budynek klubowy, a w zamieszkach rannych zostało 39 policjantów. Waśnie między kibicami przynosiły również ofiary śmiertelne, jak w 1995 roku w przypadku fana Pogoni Szczecin zamordowanego przez kibica Cracovii Kraków.

Konsekwencje wprowadzenia tej ustawy są opisane w innym miejscu (zob. Kossakowski 2014b), tutaj należy jedynie zaznaczyć, że od jej ostatniej nowelizacji nastapił gwałtowny wzrost liczby orzekanych kar. Rok 2009 był pierwszym, w którym zaczęła obowiązywać ostatnia nowelizacja ustawy. Na meczach piłkarskich doszło wtedy do 803 wykroczeń (mniej o 392 w porównaniu do roku 2008). W 2010 roku tych wykroczeń było już 1065, przestępstw zaś - 530. W 2011 roku nastąpił wzrost przestępstw na meczach piłkarskich -643 i aż 4916 wykroczeń. To wszystko przy nieznacznie mniejszej liczbie meczów 2088 w roku 2011 w porównaniu do 2103 w roku wcześniejszym. W kolejnym

\footnotetext{
3 http://www.polskieradio.pl/5/3/Artykul/938733,Donald-Tusk-kibole-zasluguja-na-potepien ie-palke-i-wiezienie [17.03.2015].

4 O czym świadczą choćby losy kibiców Lechii Gdańsk znanych ze swych antykomunistycznych wystąpień (zob. Kossakowski 2011).
} 
roku poziom przestępstw urósł. W 2012 było to 873 przestępstw w związku z meczami piłki nożnej oraz 4120 wykroczenia. Cały czas maleje liczba meczów piłkarskich zabezpieczanych przez służby policyjne - $1634 \mathrm{w}$ roku 2012 (spadek o $21,7 \%$ ). Dane z 2013 roku dotyczą tylko pierwszego półrocza i wskazują na 661 spotkań piłkarskich, 363 przestępstwa (50,6\% więcej niż w analogicznym okresie 2011 roku). Jeżeli można byłoby się pokusić o jakieś wnioski, to z pewną ostrożnością należałoby stwierdzić, że liczba wykroczeń i przestępstw na meczach piłkarskich jest niepokojąco wysoka, zwłaszcza jeśli weźmie się pod uwagę zmniejszającą się liczbę meczów piłkarskich zabezpieczanych przez policję. Rośnie także liczba skazań za przestępstwa wynikające $z$ ustawy o b. i m. W 2009 roku były to 42 (zbiorczo) przypadki, w 2010 - 188, w 2011 232, a w pierwszym półroczu $2012-225$ przypadków.

Powyższe dane mogłyby skłaniać do wniosku, że od lat dziewięćdziesiątych $\mathrm{XX}$ stulecia na polskich trybunach proces cywilizowania zachowań kibiców jest $\mathrm{w}$ odwrocie, czy wręcz mamy do czynienia z de-civilizing spurts (zob. Dunning, Murphy, Williams 1988). Jednoznaczną interpretację gmatwają jednak inne dane, dostarczane przez władze piłkarskie w Polsce: spółkę Ekstraklasa S.A. i Polski Związek Piłki Nożnej. Ta pierwsza opublikowała pod koniec 2013 roku dokument „Dekalog Klubów Ekstraklasy”, w którym wyraźnie podkreśla się wzrost bezpieczeństwa na stadionach ligowych i wspomina zaledwie o czterech znaczących incydentach w 2013 roku (wzięto pod uwagę 280 meczów). Podobne statystyki zaprezentował na przykład raport PZPN w odniesieniu do rundy jesiennej sezonu 2013/2014. Wspomina się w nim o zaledwie pięciu incydentach, których konsekwencją było przerwanie lub opóźnienie meczu.

Rzeczywiście, na polskich stadionach wydarza się coraz mniej konfrontacji fizycznych. W ostatnich trzech latach doszło tylko to dwóch stadionowych starć zwaśnionych ekip. Pierwszy przypadek miał miejsce w 2011 roku w Bydgoszczy (finał Pucharu Polski), kiedy to kibice Legii Warszawa i Lecha Poznań przeskoczyli przez ogrodzenie, doszło do zamieszek i konfrontacji z policją. Drugi przykład pochodzi z lutego 2014 roku, gdy w Warszawie doszło do bijatyki między fanami Legii i Jagiellonii Białystok. Dlaczego? Zwykle warszawscy fani usadowieni byli po przeciwnej stronie sektora gości, jednak na skutek decyzji wojewody mazowieckiego sektor ten był zamknięty (konsekwencja odpalenia środków pirotechnicznych na poprzednim meczu). Tak zwani hardcore'owi fani Legii rozmieścili się $w$ innych sektorach, $z$ których bliżej im było do białostocczan. Iskrą wzniecającą burdy stała się jednak inna okoliczność. Otóż, legioniści pokazali na swym sektorze zdobyte kilka miesięcy wcześniej flagi gości. Odwrócili je do góry nogami, co świadczyło o „symbolicznej degradacji”. Goście zareagowali z furia, atakując bramkę i płot sektora buforowego. $Z$ drugiej strony tego sektora przedarli się fani Legii. Ochrona nie „utrzymała” pozycji odgradzającej kibiców obu drużyn, którzy starli się w bójce. W większości przypadków jednak fani przeciwnych drużyn zasiadają po przeciwnych stronach aren piłkarskich, są eskortowani przez wzmocnione służby policyjne, a kibice przyjezdni 
spędzają na sektorach nawet do trzech godzin po skończonym meczu, tak aby przeciwnicy zdążyli się już rozejść do domów ${ }^{5}$.

Skąd zatem bierze się taka liczba kar za wykroczenia, jeżeli poważne incydenty (burdy, przerwanie meczu) nie zdarzają się zbyt często? Warto podkreślić, że ustawa o b.i.m. pozwala zasądzać karę grzywny czy zakazu stadionowego za takie występki, jak odpalanie pirotechniki, niepodporządkowanie się poleceniom służb porządkowych. Oznacza to, że za stanie na trybunie czy w niedozwolonych miejscach, jak schody czy ciągi ewakuacyjne, również dostaje się kary. Jeden $z$ artykułów ustawy umożliwia zastosowanie kary za... zakrycie twarzy (służby policji argumentują, że jest to stosowane przez tych, którzy chcą uniknąć identyfikacji na przykład w przypadku odpalenia rac). Wydaje się, że przynajmniej od 2009 roku credo law and order z całą stanowczością zostało inkorporowane w Polsce. Proces cywilizowania kibiców został więc wymuszony siłami państwa prawa, którego rolę w tej materii Norbert Elias wyraźnie podkreślał. Konsekwencje są takie, że coraz rzadziej zdarzają się w Polsce kolejki ligowe, kiedy to na każdym meczu (8 możliwych) zasiadają kibice przyjezdni.

Ponadto $\mathrm{w}$ Polsce nie działa na razie mechanizm rynkowy, tak skuteczny w Anglii. Jest to konsekwencja bardzo słabego poziomu sportowego polskich rozgrywek. Nie ma problemu $z$, ,istą oczekujących”, którzy byliby w stanie zapłacić więcej za możliwość oglądania gry. Profesjonalizacja polskiej piłki nożnej tak naprawdę jest procesem in statu nascendi, więc restrykcyjne prawo jest właściwie jedynym narzędziem „odgórnego” cywilizowania kibiców. Ale istnieją też mechanizmy oddolne, w strukturach kibicowskich. Od kilku lat daje się zaobserwować instytucjonalizację tego środowiska. Powstaje coraz więcej sformalizowanych ciał organizacyjnych, stowarzyszeń, które stają się partnerami do współpracy na przykład $z$ władzami klubów. Zajmują się one poprawianiem wizerunku kibiców, przez akcje charytatywne oraz zabiegi socjalizacyjne. W niektórych miastach (między innymi Gdańsk, Kraków) organizowane są konkursy plastyczne i inne akcje mające zachęcić dzieci i młodzież do przychodzenia na mecze. W Polsce powoli wprowadza się sprawdzone rozwiązania, na przykład z Niemiec. To choćby program „Kibice Razem” (wdrażany w dziewięciu miastach), współfinansowany przez władze samorządowe, którego za-

\footnotetext{
${ }^{5}$ Autor doświadcza tego typu porządku strukturalnego w swoich badaniach etnograficznych poświęconych najbardziej zagorzałym fanom. Podczas jednej podróży z Gdańska do Lubina kolumna autobusów była zabezpieczana przez pojazdy policyjne przez całą podróż. Autobusy z kibicami nie zatrzymywały się $\mathrm{w}$ miejscach publicznych (stacje benzynowe, restauracje przydrożne), lecz jedynie w „szczerym polu”. W Lubinie podjechały pod bramę wejściową sektora gości, gdzie wpuszczono fanów w otoczeniu kilkudziesięciu funkcjonariuszy policji. Z sektorem gości sąsiadowały dwa sektory buforowe bez fanów gospodarzy. Wyjście do autobusów odbyło się dopiero kilkadziesiąt minut po końcowym gwizdku. Trzeba przyznać, że możliwość bijatyk z fanami z Lubina była właściwie nierealna. Ograniczanie przestrzeni poruszania się kibiców nosi znamiona wytwarzania proksemicznego wymiaru habitusu outsiderów, a wprowadzenie ustawy o b.i.m - stanowi jego instytucjonalny/normatywny wymiar (zob. Bucholc 2012).
} 
daniem jest między innymi poznawanie potrzeb, oczekiwań i poglądów kibiców; pomoc w koordynowaniu działań; tworzenie atmosfery otwartej dyskusji i ograniczenie znaczenia przemocy wśród kibiców. Inny przykład to obowiązek zatrudnienia przez kluby osoby odpowiedzialnej za kontakty z kibicami (tzw. liaison officer). Są to przede wszystkim przedstawiciele społeczności fanowskiej, reprezentują zatem w oficjalnych strukturach „outsiderów”.

Mamy do czynienia z dwoma teoretycznie wykluczającymi się procesami. $\mathrm{Z}$ jednej strony (bardziej oficjalnej) ma miejsce stanowcza próba odseparowania światów established od outsiders (wyroki, zakazy stadionowe, zamykanie sektorów czy stadionów). Z drugiej strony („pełzającej”) pojawiają się inicjatywy „inkorporujące” kibiców w strumień cywilizowania. Pytanie, które należy tutaj rozstrzygnąć, jest następujące: czy outsiderzy chcą być „zinkorporowani”? W poszukiwaniu odpowiedzi warto rozpocząć od pewnego założenia na temat tego, kim jest „outsider”. Oznacza to bycie „rozpoznawanym jako taki przez otoczenie i posiadanie odpowiedniego zbioru zachowań, ocen, poglądów i dyspozycji, które w oczach kompetentnego (poprawnie uspołecznionego) obserwatora stanowią podstawę rozpoznania jednostki jako przynależnej do określonej społecznej kategorii" (Bucholc 2012, s. 228). Kategorią społeczną jest „kibol” 6 , outsider, w oczach kompetentnego, „poprawnie” uspołecznionego obserwatora dopuszczający się działań nieprzystających do cywilizowanego świata. Ich (bycie outsiderem wynika z inności grupowej) cechy służą dobrze do oszacowania innych zjawisk, definiowania ich tożsamości: „Lekarz leczy, strażak gasi pożary, a kibol «dymi». Niewiele rozumie ze współczesnego świata i boi się go - więc "dymi»" 7 . Zauważmy, że „inność" outsidera funkcjonuje tutaj jako społeczna heurystyka - nie wymagająca dalszych, refleksyjnych dociekań.

Definiowanie tożsamości outsiderów przez przedstawicieli „osiadłych” niekiedy przybiera nazbyt schematyczne formy, poddawane krytyce przez innych

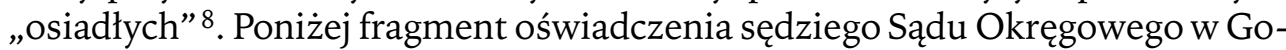
rzowie Wielkopolskim na temat zeznań jednego z policjantów:

„Szczególnie groteskowo wygląda karta poglądowa nr [...], gdzie jeden ogolony na łyso oskarżony M. zestawiony jest $z$ trzema osobami owłosionymi. Oczywiście tym złym na jakiego należy wskazać jest M. Bo taki jest lansowany stereotyp

\footnotetext{
6 Warto podkreślić, że słowo „kibol” ma źródła w gwarze poznańskiej, w której oznacza kibica. Określenie to dawno już jednak przestało mieć znaczenie regionalne i zostało zaadaptowane w celach definiowania „innego" bez względu na miasto w Polsce.

7 Fragment felietonu autorstwa Wojciecha Maziarskiego, publicysty „Gazety Wyborczej” (http://wiadomosci.gazeta.pl/wiadomosci/1,114873,11931367,_Przez_caly_tydzien_narastala_w Polsce atmosfera grozy .html [17.06.2014]).

8 Słowo „osiadli” jest próbą polskiej translacji (zob. Bucholc 2012) słowa established używanego przez Eliasa i Johna S. Scotsona pt. The Established and the Outsiders (1994). Faktycznie odnosi się ono do charakteru książki Eliasa i Scotsona (chodziło bowiem o relację między mieszkańcami osiadłymi a nowymi, „obcymi”). W tekście stosuję to tłumaczenie w szerszym kontekście, na przykład gdy chodzi o established w pewnym dyskursie i outsiderów, którzy w ramach tego dyskursu się mieszczą.
} 
kibica, czy raczej kibola, jak to określono w niektórych mediach - musi być duży, łysy i zły. Jeżeli to ma być argument, to raczej argument śmieszny, gdyż taką samą fryzurę ma zarówno sędzia orzekający w niniejszej sprawie jak i cześć sędziów Sądu Okręgowego oraz część prokuratorów i wielu policjantów. Czy to też oznacza, że są podejrzani? [...] $]^{9}$.

Elias i Scotson dowodzą, że „outsiderzy” przyjmują ocenę „osiadłych”, uznając się za "gorszych”. W przypadku „kiboli” sprawa wygląda nieco inaczej. Wykorzystują oni etykietę dewiantów w celu definiowania siebie i ironicznego żonglowania nią w pokazach performatywnych. Dobrym przykładem są oprawy: „Łamiemy przepisy” (Korona Kielce - oprawa zawierała również „trupią czaszkę" w czapce kucharskiej, metafora odnosiła się do przygotowania „potrawy kibolskiej”, której głównym „składnikiem” okazały się nielegalne race), „Nienawidzimy wszystkich” (Legia Warszawa), „Lepiej być chuliganem, niż kraść na państwowej posadzie” (Gryf Słupsk), „Kibolski Klub Sportowy” (Lech Poznań), „To my bandyci z Traugutta” (Lechia Gdańsk), Kibice Korony Kielce „potwierdzili” swój status sloganem z oprawy meczowej: „We are still kiboling”. Mówi on - tak, ciągle jesteśmy „kibolami”. Czy to specyficzna odmiana „jaźni odzwierciedlonej”? Kibice stają się takimi, jakimi widzą ich inni. Piętno, które staje się źródłem tożsamości? Jesteśmy „obcymi”, ale to nie tylko nas nie degraduje, ale wzmacnia (w Anglii znane jest motto kibiców Millwall: „No one likes us, We don’t care”). Elias dostrzegał, że „treść zbiorowych wyobrażeń obu grup o sobie samych i o sobie nawzajem staje się narzędziem wzmacniania jednej z nich, a osłabiania drugiej: outsiderzy, których obraz kształtowany jest negatywnie, tracą — można by powiedzieć - energię niezbędną do wytworzenia grupowej więzi i solidarności, zaś osiadli, których obraz jest pozytywny, taką energię zyskują" (Bucholc 2012, s. 230).

W przypadku „kiboli” to zjawisko, jak się wydaje nie następuje. Stanowią oni grupy o silnym poczuciu grupowej więzi i solidarności (wyrażanych między innymi w metaforyce „braterstwa”), które przeciwstawiają się zapędom „osiadłych” (rządu, niektórych mediów, części opinii publicznej) do „cywilizowania”. Nie spełniają oczekiwań, by kibicować „piknikowo” (bez stania, bez rac itp.), co więcej - dają się poznać przez metaforykę „wojenną":

„[...] Obecna władza wytoczyła wobec nas kibiców wojnę. [...] Póki co wychodzi $z$ tego wojna na wyniszczenie i wykrwawienie. Jakie jest bowiem zdziwienie władzy, że kibole prowadząc wojnę partyzancką i zaczepną nadal odpalają piro, nadal robią oprawy antyrządowe. [...] Prowadzimy cały czas wojnę $z$ wrogiem $\mathrm{nr}$ 1. Już nie z policją - to są tylko pionki wykonawcze. [...] O swoje prawa i wolność walczymy od 3 lat z systemem — prowadzimy walkę, która nas wiele kosztuje, ale wiemy, o co walczymy. Wiemy, że za to warto w przenośni przelewać krew, poświęcać ofiary i wyrzeczenia. [...] Polska-kibolska Walcząca!"10.

${ }^{9}$ Notka opublikowana w miesięczniku „To My Kibice” 2014, nr 4, s. 39.

10 Tamże. 
Metaforyka „wojenna” pomaga określić podstawowe fault lines polskich kibiców. Richard Giulianotti (1999) pokazuje, że na tożsamość w futbolu można patrzeć dwojako, w formie „semantycznej” i „syntaktycznej”. W tej pierwszej jednostki i grupy definiują się przez odpowiedź na pytanie: „kim jestem/jesteśmy". Natomiast w tym drugim przypadku kluczowym pytaniem jest: „kim nie jestem/jesteśmy”. Kibice fanatyczni mogą definiować się jako ostoja tradycji i „prawdziwego” kibicowania. To dyskurs autentyczności, który zawiera się również w mechanizmie dzielenia światów, oznacza ekskluzywność, ponieważ bycie autentycznie „kimś” wytacza automatycznie granice. Tworzy się „system klasyfikacji, składający się z binarnych przeciwieństw” (Alexander 2010, s. 113). Antagonizmy kibiców dotyczą czterech wymiarów: politycznego (systemowego), medialno-biznesowego, normatywnego (kulturowego), wewnętrznego.

„Polityka nie pokona fanatyka” (Śląsk Wrocław), „Donald matole twój rząd obalą kibole" (ogólnopolskie znaczenie), a także wiele haseł antypolicyjnych, antyrządowych (w zależności od kontekstu „sprawy”, dotyczących niekiedy władz samorządowych) stapia się w istotę dystynktywną wymiaru pierwszego. „Nasza pasja, która nie ma końca. Siła miłości niszczy siłę pieniądza (kibice Legii Warszawa w odpowiedzi na działania byłego właściciela klubu, spółki ITI), "Gówno prawda" (choreografia sympatyków Legii stworzona na wzór logotypu "Gazety Wyborczej”). Takie są wybrane składniki opozycji wobec mediów i biznesu. „Precz z komuną” (hasło ogólnopolskie) czy „Zakaz pedałowania” (Wisła Kraków) odnoszą się do sfery norm, wartości i wzorów kulturowych. Na trybunach ultras w Polsce dominują treści konserwatywne, odwołujące się także do ważnych dat i postaci historycznych (np. żołnierze wyklęci). Natomiast opozycje „wewnętrzne” koncentrują się na rywalizacji z kibicami innych klubów (w środowisku kibiców funkcjonują „zgody” i „kosy”; ta pierwsza oznacza przymierze, przyjaźń; ta druga - wrogość). Słuszny zatem wydaje się postulat, by nie ograniczać się do poszukiwań różnic i podobieństw w kontekście międzynarodowym, ale również dostrzegać je na gruncie lokalnym (within-case variations; zob. Spaaij'a 2006, s. 6).

\section{PLEMIENNE FIGURACJE W EPOCE INDYWIDUALIZMU}

Wspólnoty kibiców są hermetyczne i wewnętrznie spójne. Określenie ordered segmentation może być przydatne, ale tylko w wymiarze geograficznym. W poszczególnych miastach całe osiedla są „za” jednym klubem, a „przeciwko" innemu. Nie są one jednak homogeniczne pod względem klasowym. Zróżnicowanie kultury kibicowania dokonuje się na wielu poziomach. Ma to związek z „dialektyką kontroli” (Dunning 2003, s. 90). Wraz ze wzrostem kontroli władz, policji, „penetrującego" prawa wzrasta dialektyka kontroli fanów - są zmuszeni do aktywności na coraz bardziej skomplikowanym poziomie logistycznym i strukturalnym. Dowodem są choćby poczynania stowarzyszenia 
kibiców Lechii Gdańsk, które zorganizowało dwie konferencje pt. „Pirotechnika jest bezpieczna”. Zaproszono prawników, władze lokalne, funkcjonariuszy straży pożarnej. Prezes stowarzyszenia przedstawił ekspertyzy prawne oraz materiałowe, a wnioski $z$ nich wysunął również na spotkaniu $z$ posłami $\mathrm{w}$ polskim parlamencie. Stowarzyszenia kibicowskie poszerzają pola działalności o sferę charytatywną, wychowawczą, kulturową, czasami ideową i historyczną. Opozycyjna „linia podziału” ma ogromne znaczenie w budowaniu tożsamości kultury, ale widoczne są też ruchy zmierzające ku formie „semantycznej” („kim jesteśmy").

Nie bez znaczenia jest również wzrastająca współzależność w polu piłki nożnej. Sport ten można potraktować jako „arenę”, na której zróżnicowani gracze (sponsorzy, media, władze klubów, samorządy, związki piłkarskie, piłkarze, organizacje pozarządowe, kibice) „wykuwają” swoją pozycję za pomocą innego typu kapitałów. Żadna struktura nie dysponuje wszystkimi typami zasobów, by wykluczyć resztę. Piłka nożna jest zatem figuracją konstruowaną przez relacje wspomnianych „graczy”. „Relacje te zachodzą we względnie stabilnych, różniących się stopniem złożoności i historycznie zmiennych układach jednostek i ich wzajemnych powiązań: $\mathrm{w}$ ramach tych układów następują asymetryczne przesunięcia władzy" (Bucholc 2013, s. 28). Przesuwanie się władzy skutkuje nieustanną grą „napięcia-równowagi”, której zróżnicowanie związane jest z różnymi typami „polaryzacji” (Elias, Dunning 1986, s. 200-202), powstającymi w stosunkach wspomnianych graczy (inna polaryzacja rodzi się między sponsorem tytularnym rozgrywek a klubami, jeszcze inna między kibicami a związkiem piłkarskim).

Czy kibice tworzą figurację? Składa się ona $z$,jednostek tworzących różne relacje w najrozmaitszych celach: aktorzy przychodzą i odchodzą, wciąż zmieniają się przedmioty ich działania, pojawiają się nowe kategorie celów i nowe techniki wchodzenia $\mathrm{w}$ relacje. $\mathrm{Z}$ tej różnorodności wyłaniają się jednak a posteriori pewne trwałe prawidłowości, które jednostki przyjmują nieświadomie lub na wpół świadomie. Jedną z tych prawidłowości stanowi stratyfikacja figuracji, którą można opisać właśnie dzięki pojęciu poziomu integracji” (Bucholc 2013 , s. 29). Poziom integracji rośnie z czasem - pogłębianie zaufania w środowisku kibiców to proces długotrwały, ale rzutujący na hierarchię. Widać to na przykład w zasadach sektora kibicowskiego Legii („Żyleta”): „Kibice $z$ niskim stażem meczowym proszeni są o zajmowanie miejsc na bocznych sektorach trybuny ULTRAS" ${ }^{11}$. Droga do centrum wiedzie z zewnętrznych rubieży kibicowskiego środowiska. Wierność i oddanie znaczeniom kardynalnym dla „świadomości zbiorowej” stanowią klucz do osiągnięcia pozycji autorytetu cenionego przez pozostałych kibiców. Tak duże mają znaczenie fani „oddani” przez lata, ci, którzy zaliczyli dużą liczbę wyjazdów, a w kręgach

11 http://legionisci.com/news/38827_Zasady_na_nowej_Zylecie.html [03.07.2014]. 
chuligańskich - jednostki nie uciekające z pola walki, nadstawiające karku za resztę.

Hierarchia opiera się na utrwalaniu tradycji i starszeństwie. Jak w każdej wspólnocie „aktorzy przychodzą i odchodzą”, co związane jest choćby z wymianą pokoleniową. Inną przyczynę wymienia kibic Wigier Suwałki: „Jeżeli chodzi o emigrację, to nasza ekipa mocno odczuwa ten fakt i gdyby nie fala napływu młodych i determinacja kilku osób, to ciężko byłoby z nami. Większość najlepszych chłopaków wyjechała za granicę, lub do innych miast naszego kraju w poszukiwaniu pracy" (Wigry... 2014, s. 48). Przedmioty działania, cele i nowe techniki wchodzenia $\mathrm{w}$ relacje zmieniają się jako forma wspierania klubu, który jednak wciąż pozostaje uniwersum symbolicznym. Proces „cywilizowania” powoduje, że coraz rzadziej kibice muszą stawać w jego obronie na gruncie chuligańskim, coraz wyraźniej w Polsce dominuje sfera ultras, organizująca się wokół symbolicznego przedstawienia, choreograficznego spektaklu. Coraz częściej kibicowanie staje się performansem kulturowym, w którym przemoc rugowana jest nie tyle na skutek świadomego odśrodkowego działania, ale w konsekwencji procesów społeczno-legislacyjnych.

Wartość współzależności o największym ciężarze gatunkowym objawia się jednak w samym akcie kibicowania. „Jeden głos”, „tysiące gardeł” czy bardziej „surowe” określenie „konkretne pierdolnięcie” oznaczają konwergencję pojedynczych jednostek we wspólnotowej energii emocjonalnej. Akt kibicowania jest w swej specyfice skrajnie wspólnotowy, niweluje jednostkowe dystynkcje klasowe, wiekowe, wykształceniowe czy płciowe. Mowa o zachowaniach „aborygeńskich” (Antonowicz, Kossakowski, Szlendak 2012), które swą niszowością przeciwstawiają się powszechnej tendencji dominującej $\mathrm{w}$ „kulturze indywidualizmu" (Jacyno 2008). Tendencją wyróżniającą się przez to, że „nie potrzebujemy wielkich, quasi-plemiennych, zbiorowych świąt, opartych na Durkheimowskiej solidarności mechanicznej, w których jednostki miałyby szanse zachowywać się $\mathrm{w}$ taki sam sposób i czerpać $\mathrm{z}$ tej identyczności poczucie jedności, przynależności i tożsamości zbiorowej” (Bucholc 2013, s. 212). Okazuje się jednak, że niektórzy potrzebują takiego poziomu emocjonalnego zidentyfikowania $z$ grupą:

Jak jest bardzo dużo ludzi to mnie osobiście czyni wolnym. Na co dzień $w$ domu czy jadac samochodem czy będac ze swoją druga potowa, siedzac przy stole rodzinnym, raczej nie wstanę i nie zacznę sobie skakać, bo będę wyglądat delikatnie mówiac zabawnie. Na stadionie jednak każdy. Wystarczy, że jeden, jak się nakręcimy do dopingu i skaczemy, jak jedna osoba ściagnie koszulkę, za chwile się okazuje, że potowa jest bez koszulek. To jest niesamowite poczucie wolności, gdzie przez te 90 czy 120 minut mam swój świat $i$ moge się, $w$ granicach prawa oczywiście, zachowywać tak jak się zachowuję. Nie mówię tam o jakichśs wybrykach typu odpalanie racy czy wrzucaniu na przeciwników stów uważanych $z a$ wulgarne, bo to też się robi $i$ to jest pitka nożna $i$ tak to będzie wygladało. Będac na trybunach $i$ będac ta jedna grupa wszyscy sie zachowuja tak samo co daje niesamowite 
poczucie, bo się okazuje: kurde nie jestem wariatem. Tutaj jest kilka tysięcy ludzi, którzy reaguja tak samo jak ja.

Jest to wypowiedź fana Lechii Gdańsk, któremu wtóruje jego kolega, również wierny klubowi z Gdańska:

Czuje się taka emocjonalna więź, nie tyle $z$ drużyna, co z tymi ludźmi dookota $i$ tworzy jedna, wielka wspólnotę. Razem się przeżywa, razem się smuci. Myślę, że to jest jeden $z$ powodów, dlaczego te grupy sa takie silne. [...] Wiadomo, z niektórymi, można powiedzieć jest sie przyjaciótmi, z niektórymi kolegami, niektórymi lepszymi kolegami, gorszymi, ale to już taka grupa scementowana powstała. Z czasem ktoś się wykruszy, ktoś dojdzie nowy, ale jednak powstaje... To w ramach, to chyba cała grupa, ogólnie kibiców, tworzy się na takie małe spoteczności. Czy to $w$ ramach dzielnic, czy to ramach jakis grup tematycznych, czy to $w$ ramach, jak u nas stowarzyszenia. Powstaja takie mate spoteczności, bardzo zżyte ze soba, które mają kontakt na co dzień.

Czy takie wypowiedzi świadczą o „odwrocie” od indywidualistycznych tendencji we współczesnej kulturze? Tak jak w sporcie od lat ludzie poszukiwali źródła ekscytacji, tak w akcie kibicowania niektórzy mogą poszukiwać źródeł wspólnotowości. O tym, jaki będzie tego skutek, najpewniej przekona nas proces społeczno-historyczny.

\section{BIBLIOGRAFIA}

Alexander Jeffrey C., 2010, Znaczenia społeczne. Studia z socjologii kulturowej, tłum. Stanisław Burdziej, Jacek Gądecki, Nomos, Kraków.

Antonowicz Dominik, Kossakowski Radosław, Szlendak Tomasz, 2012, Pitkarz jako marka i peryferyjny kibic jako aborygen. O wybranych spotecznych konsekwencjach komercjalizacji sportu, „Kultura i Społeczeństwo", nr 3.

Armstrong Gary, 1998, Football Hooligans: Knowing the Score, Berg, Oxford.

Armstrong Gary, Giulianotti Richard, 2001, Fear and Loathing in World Football, Berg, Oxford.

Bairner Alan, 2006, The Leicester School and the Study of Football Hooliganism, „Sport in Society”, nr 4. Best Shaun, 2010, The Leicester School of Football Hooliganism: An Evaluation, „Soccer and Society”, nr 5.

Bucholc Marta, 2012, Osiadli i outsiderzy. Norbert Elias o inności $i$ wykluczeniu społecznym, w: Maciej Gdula, Aleksandra Grzymała-Kazłowska, Renata Włoch (red.), Nowe rzeczywistości społeczne, nowe teorie socjologiczne. Dyskusje i interpretacje, Scholar, Warszawa.

Bucholc Marta, 2013, Samotność dtugodystansowca. Na obrzeżach socjologii Norberta Eliasa, Wydawnictwo Naukowe PWN, Warszawa.

Dunning Eric, 1992, The Social Roots of Football Hooliganism: A Reply to the Critics of the 'Leicester School', w: Richard Giulianotti, Norman Bonney, Mike Hepworth (red.), Football, Violence and Social Identity, Routledge, London.

Dunning Eric, 1999, Sport Matters: Sociological Studies of Sport, Violence and Civilization, Routledge, London.

Dunning Eric, 2000, Towards a Sociological Understanding of Football Hooliganism as a World Phenomenon, „European Journal on Criminal Policy and Research”, nr 2.

Dunning Eric, 2003, Football Hooliganism in Britain: 1880-1989, w: Patrick Murphy, John Williams, Eric Dunning (red.), Football on Trial: Spectator Violence and Development in the Football World, Routledge, London. 
Dunning Eric, Murphy Patrick, Williams John, 1986, Spectator Violence at Football Matches: Towards a Sociological Explanation, „The British Journal of Sociology”, nr 2.

Dunning Eric, Murphy Patrick, Williams John, 1988, The Roots of Football Hooliganism, Routledge \& Kegan Paul, London.

Dunning Eric, Malcolm Dominic, Waddington Ivan, 2004, Figurational Sociology and the Development of Modern Sport, w: Eric Dunning, Dominic Malcolm, Ivan Waddington (red.), Sport Histories: Figurational Studies of the Development of Modern Sports, Routledge, London.

Elias Norbert, 1986a, Introduction, w: Norbert Elias, Eric Dunning, Quest for Excitement: Sport and Leisure in the Civilizing Process, Blackwell, Oxford.

Elias Norbert, 1986b, On Essay on Sport and Violence, w: Norbert Elias, Eric Dunning, Quest for Excitement: Sport and Leisure in the Civilizing Process, Blackwell, Oxford.

Elias Norbert, 2008, Spoleczeństwo jednostek, tłum. Janusz Stawiński, Wydawnictwo Naukowe PWN, Warszawa.

Elias Norbert, 2010, Czym jest socjologia?, tłum. Bogdan Baran, Aletheia, Warszawa.

Elias Norbert, Dunning Eric, 1986, Leisure in the Spare-time Spectrum, w: Norbert Elias, Eric Dunning, Quest for Excitement: Sport and Leisure in the Civilizing Process, Blackwell, Oxford.

Elias, Norbert, Scotson John S., 1994, The Established and the Outsiders, Sage, London.

Giulianotti Richard, 1989, A Critical Overview of British Sociological Investigations into Soccer Hooliganism in Scotland and Britain, „Working Papers on Football Violence”, nr 1.

Giulianotti Richard, 1999, Football: A Sociology of the Global Game, Polity Press, Cambridge.

Giulianotti Richard, 2005, Sport: A Critical Sociology, Polity Press, Cambridge.

Giulianotti Richard, 2011, Sport Mega Events, Urban Football Carnivals and Securitised Commodification: The Case of English Premier League, „Urban Studies”, nr 15.

Giulianotti Richard, Armstrong Gary, 2002, Avenues of Contestation: Football Hooligans Running snd Ruling Urban Spaces, „Social Anthropology”, nr 2.

Jacyno Małgorzata, 2008, Kultura indywidualizmu, Wydawnictwo Naukowe PWN, Warszawa.

Kamiński Andrzej, 2012, Typologia kibiców pitkarskich, w: Wiesław Pływaczewski, Bernard Wiśniewski (red.), Przestępczość stadionowa. Diagnoza i przeciwdziałanie zjawisku, WSPol, Szczytno.

Kennedy David, Kennedy Peter, 2010, Towards a Marxist Political Economy of Football Supporters, „Capital and Class”, nr 2.

Kerr John H., 1999, Understanding Soccer Hooliganism, Open University Press, Buckingham.

King Martin, Knight Martin, 2008, Hoolifan, Trolsen communicate!, b.m.w.

Kossakowski Radosław, 2011, Biato-zielona Solidarność, w: Karolina Ciechorska-Kulesza, Radosław Kossakowski, Paweł Łuczeczko (red.), Kultura Solidarności. Socjologiczno-antropologiczne analizy kulturowego dziedzictwa „Solidarności”, Orbis Exterior, Pszczółki.

Kossakowski Radosław, 2014a, Performans na trybunach. O kulturowo-dramaturgicznym aspekcie kibicowania, „Przegląd Humanistyczny AGH”, nr 1.

Kossakowski Radosław, 2014b, Stadiony pitkarskie — bezpieczne światynie futbolu czy bastiony chuligaństwa?, w: Artur R. Kozłowski, Ewa Polak (red.), Międzynarodowe i wewnętrzne uwarunkowania bezpieczeństwa w Polsce, Prace Naukowe Wyższej Szkoły Bankowej w Gdańsku, t. 33.

Malcolm Dominic, 2012, Sport and Sociology, Routledge, London.

Marsh Peter i in., 1978, The Rules of Disorder, Routledge \& Kegan Paul, London.

Peisert Arkadiusz, 2013, Socjogeneza sportu wedtug Norberta Eliasa, w: Radosław Kossakowski, Krzysztof Stachura, Anna Strzałkowska, Magdalena Żadkowska (red.), Futbol i cała reszta. Sport w perspektywie nauk społecznych, Orbis Exterior, Pszczółki.

Pearson Geoff, 2012, An Ethnography of Football Fans: Cans, Cops and Carnivals, Manchester University Press, Manchester.

Pennant Cass, 2009, Congratulations: You have just met the I.C.F., Trolsen communicate!, b.m.w. 
Spaaij Ramón, 2006, Understanding Football Hooliganism: A Comparison of Six Western European Football Clubs, Amsterdam University Press, Amsterdam.

Taylor Ian, 1971, Football Mad: A Speculative Sociology of Football Hooliganism, w: Eric Dunning (red.), The Sociology of Sport: A Selection of Readings, Frank Cass, London.

Tetłak Karolina, 2012, Podatkowe aspekty pitkarskich mistrzostw Europy UEFA EURO 2012, „Rocznik Naukowy AWFiS w Gdańsku”, t. 22.

Tsoukala Anastassia, 2009, Football Hooliganism in Europe: Security and Civil Liberties in the Balance, Palgrave Macmillan, Basingstoke.

Wigry... 2014, Wigry Suwatki, „To my kibice”, nr 4.

\section{HOOLIGANISM OR FIGURATION IN THE CIVILIZING PROCESS? RECEPTION OF THE LEICESTER SCHOOL AND THE WORLD OF POLISH FOOTBALL FANS}

\section{Sum mary}

The main aim of this article is to consider the topicality of the theoretical achievements of the Leicester School, formed by the students and continuers of Norbert Elias's ideas, with Eric Dunning at their head. The author presents the main theses on stadium hooliganism which Dunning and his team formulated on the basis of a socio-historical analysis. The English researchers connect the behaviour of football fans with their class origins, with patterns of 'street' socialization, with masculinism, and with violence constituting an important aspect of daily life. They show that the social environment from which the majority of hooligans originate has not been included in the broader stream of the civilizational process. Then the author, in describing Polish football fans, makes use of certain elements of Norbert Elias's process sociology (constituting Dunning's analytical tool). History shows that the sub-culture of football fans is 'becoming civilized', although not in a uniform manner. The concept of figuration could be a valuable analytical tool for describing the community of football fans, as it is not a society separated from the outside world, but remains in a specific interdependence with it. In the analysis, the dichotomy between 'settlers' and 'outsiders' is also helpful.

\section{Key words/słowa kluczowe}

Norbert Elias; football fans / kibice piłkarscy; hooligans / chuligani; figuration / figuracje; civilizing process / proces cywilizowania 